\title{
The comparison of surface hardness between thermoplastic nylon resin and heat-cured acrylic resin
}

\author{
Marina Utami, Renny Febrida, Nina Djustiana
}

Department of Dental Material Science and Technology Faculty of Dentistry Universitas Padjadjaran

\begin{abstract}
The surface hardness level of a denture base material is related to resistance of abrasion, scratch, polishing and water sorption. Nowadays, thermoplastic nylon resins and heat-cured acrylic resins are used as denture base materials. Denture base must be immersed in water to maintain its humidity. The objective of this research was to compare the surface hardness level between thermoplastic nylon resins and heat-cured acrylic resins. Materials used for the research were thermoplastic nylon resins from Valplast and heat-cured acrylic resins QC-20, with sample size of $64 \times(10 \pm 0.03) \times(2.5 \pm 0.03) \mathrm{mm}$. Surface hardness is measured with Vickers Microhardness Tester and the data were analyzed by ANOVA method. The results showed that comparison ratio of surface hardness level between thermoplastic nylon resins and heat-cured acrylic resins before immersion is 3.2:7.3 VHN respectively, while the comparison value of both resins after immersion is 2.8:6.6 VHN. In conclusion, the surface hardness level of thermoplastic nylon resins is lower compared to heat-cured acrylic resins. This result is due to thermoplastic nylon resin's higher porosity, its different polymer chains, and the plasticizers effect after immersion in water.
\end{abstract}

Key words: Thermoplastic nylon resins, heat-cured acrylic resins, surface hardness

\section{INTRODUCTION}

Base is an important part of denture since it plays a role as a supporter of the tissues around teeth. ${ }^{1}$ The base material of denture has been developed in order to fulfill some base criteria of ideal denture which have to meet some physical and mechanical requirements. Some requirements that have to be fulfilled are no color change, low porosity, stability on dimension change, non toxic, depression strength and high hardness, low water sorption, and rigidness for producing good stability. ${ }^{2-4}$

A popular material for denture base nowadays is made of thermoplastic nylon resin. One of thermoplastic nylon resin brand is Valplast.
Besides thermoplastic nylon resin, another base material for denture that has been used over the past 60 years in dentistry is heat-cured acrylic resin. ${ }^{5}$ Acrylic resin commonly has monomer remains after polymerization. The monomer remains can act as plasticizer so that it can influence the physical and mechanical natures of acrylic resin. ${ }^{5-7}$ Water absorption in resin can also act as plasticizer which is able to change the mechanic nature of the resin. ${ }^{8,9}$

Porosity and high water absorption will facilitate debris and organic materials to attach on denture base, and they can make resin more plastic and flexible as well. 9,10 Porosity in denture base, whether the base is made of thermoplastic nylon resin or heat-cured acrylic resin, can 
enhance water absorption since denture base is always in contact with mouth liquid and it is suggested to soak it in water or in denture cleaner liquid during night time. Water absorption may cause surface hardness of its base's plate reduces. Besides, porosity will also influence the hardness of denture base's surface. ${ }^{5,7}$

\section{MATERIALS AND METHODS}

The material used in this research was thermoplastic nylon resin, Valplast brand and heat-cured acrylic resin QC-20 brand. The number of samples were 5 plates of thermoplastic nylon resin and 5 plates of heat-cured acrylic resin, size $64 \times(10 \pm 0.03) \times(2.5 \pm 0.03) \mathrm{mm}$. The samples were softened and polished with the same treatment.

After polishing, surface hardness of the samples were tested in order to get early number of surface hardness, then the samples were soaked in aquades for two days with temperature $37 \pm 1^{\circ} \mathrm{C} .{ }^{11,12}$ After two-day soaking, another surface hardness test was conducted using Vickers Microhardness Tester. Vickers Hardness Number was got by dividing the force with indentation result area. The equation is as follow: ${ }^{13,14}$

$\mathrm{VHN}=\mathrm{F} / \mathrm{A}=2 \mathrm{~F} \sin (\mathrm{a} / 2) / \mathrm{d}^{2}=1.8544 \mathrm{~F} / \mathrm{d}^{2}$

Note: $\mathrm{VHN}=$ Vickers Hardness Number; $\mathrm{F}=$ test force $(\mathrm{kg}) ; \mathrm{A}=$ width of surface after pressure $\left(\mathrm{mm}^{2}\right)$; $d=$ average diagonal length after pressure $(\mathrm{mm})$; $\alpha=$ angle of diamond indenter surface $\left(136^{\circ}\right)$

\section{RESULT}

The comparison of surface hardness number of thermoplastic nylon resin and heat-cured acrylic resin before soaking was 3.2:7.3 VHN. After they were soaked for 2 days, the result was, the comparison of surface hardness number of thermoplastic nylon resin and heat-cured acrylic resin was 2.8:6.6 VHN.

\section{DISCUSSION}

The study on different resin materials, between thermoplastic nylon resin and heat-cured acrylic resin before soaking gives a significant effect on surface hardness number. The research result shows that the surface hardness number of thermoplastic nylon resin is lower than heat-cured acrylic resin. One of the causes of surface hardness number's difference between thermoplastic nylon resin and heat-cured acrylic resin is the porosity difference which is formed in thermoplastic nylon resin and heat-cured acrylic resin. This is in line with IIImida ${ }^{15}$ that indicated thermoplastic nylon resin porosity is higher than heat-cured acrylic resin, that is 1.9:1.

Higher porosity in thermoplastic nylon resin may be caused by the injection method which

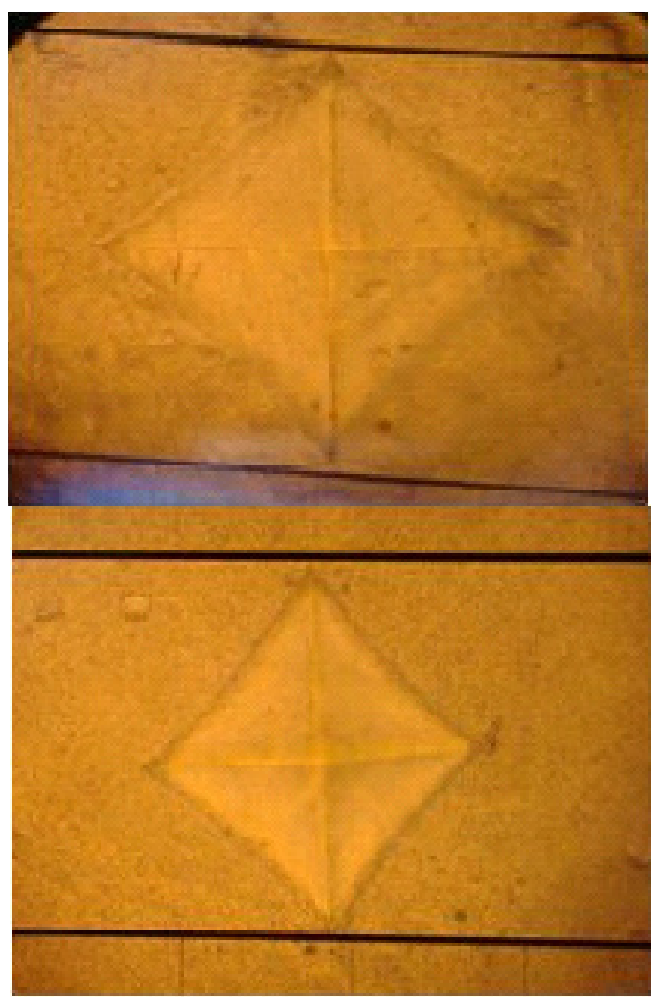

Figure 1. Surface hardness indentation after 2-day soaking Upper: Thermoplastic nylon resin; Lower: Heat-cured acrylic resin.

Table 1. Data of surface hardness number measurement result

\begin{tabular}{|c|c|c|c|c|c|c|c|c|c|c|c|c|}
\hline \multirow{2}{*}{$\begin{array}{c}\text { Surface hardness } \\
\text { number (VHN) }\end{array}$} & \multicolumn{5}{|c|}{ Thermoplastic nylon resin(*) } & \multirow{2}{*}{$\begin{array}{c}\text { Average } \\
\left({ }^{*}\right)\end{array}$} & \multicolumn{5}{|c|}{ Heat-cured acrylic resin(*) } & \multirow{2}{*}{$\begin{array}{l}\text { Average } \\
\left({ }^{*}\right)\end{array}$} \\
\hline & 1 & 2 & 3 & 4 & 5 & & 1 & 2 & 3 & 4 & 5 & \\
\hline Before soaked & 3.18 & 3.11 & 3.28 & 3.25 & 3.24 & 3.2 & 7.68 & 6.89 & 7.36 & 7.55 & 7.13 & 7.3 \\
\hline $\begin{array}{l}\text { After they were soaked } \\
\text { for } 2 \text { days }\end{array}$ & 2.8 & 2.71 & 2.80 & 2.86 & 2.84 & 2.8 & 6.98 & 6.73 & 6.15 & 6.76 & 6.21 & 6.6 \\
\hline
\end{tabular}


is not suitable with the manufacturer procedure suggestion and the monomer ratio which is higher than polymer. The number of monomer which is more than polymer is intended to enhance the stream energy of the dough when it is poured into the mould. Besides, thermoplastic nylon resin also contains linear tie (single polymeric chain) in which hexamethylenadiamine and carboxyl acid in thermoplastic nylon resin will form long tied polyamide. ${ }^{16,17}$ The linear tie in thermoplastic nylon resin is weaker than branched, cross-linking ties, and the network formed in polymer. The linear tie in thermoplastic nylon resin is not durable enough to solvent and surface pressure compared to other types of polymer ties. ${ }^{3,16}$

Higher surface hardness in heat-cured acrylic resin compared to thermoplastic nylon resin is caused by the addition of cross-linking material in the acrylic resin, diethyl glycol dimetacrilat $1-2 \%{ }^{3}$ The cross-linking material can enhance surface hardness and reduce water absorption amount of an denture base. ${ }^{4}$ Polymer with more cross-linking will be brittle, harder, and more durable to solvent than polymer without cross-linking. ${ }^{2}$ Polymer cross-linking tie is formed by crossed-linking homopolymer with linear chain of single cross-linking material until it forms three dimensional structure with strong ties between the chains. ${ }^{3,16}$

After 2-day soaking, the surface hardness number of thermoplastic nylon resin was lower than heat-cured acrylic resin. The 2-day soaking in water is intended to find out the effect of water absorption on surface hardness nature in thermoplastic nylon resin and heat-cured acrylic resin. ${ }^{7}$ The possible reason to describe the reduction of resin surface hardness number after it was soaked in water was, water gives plasticizer effect to resin. Lower surface hardness in thermoplastic nylon resin than heat-cured acrylic resin after 2-day soaking was affected by higher porosity in thermoplastic nylon resin.

In its development, although the nature of thermoplastic nylon resin has been updated by adding glass reinforced nylon material (glass or fiber) in order to reduce water absorption, but the fiber in thermoplastic nylon resin has the ability to absorb water. This might be a factor that causes the reduction of thermoplastic nylon resin surface hardness after 2 day soaking. ${ }^{18}$
The reduction of heat-cured acrylic resin surface hardness after 2 day soaking might be caused by water that acts as plasticizer. Water diffuses into polymer so it loosens polymer chain tie and reduces the mechanical nature of polymer that was surface hardness. ${ }^{19}$ When heat-cured acrylic resin was soaked, monomer residue was released and water absorption happened at the same time. This process facilitates water diffusion into the polymer. Besides, the time of soaking also affects the amount of water that diffuses into the polymer. According to Azevedo et al. ${ }^{7}$ reduction of surface hardness can be noticed after it was soaked for 2 days. ${ }^{7}$ Cross-linking tie in heatcured acrylic was not easily degraded by water absorption, while linear tie in thermoplastic nylon resin was not durable enough to solvent and surface pressure. Besides, thermoplastic nylon resin was basically hygroscopic. Humidity as the result of water absorption was able to reduce resin mechanic nature, that is, surface hardness. ${ }^{1,3,16,18}$

The surface hardness number of thermoplastic nylon resin or heat-cured acrylic resin that had been soaked in water will reduce. The conclusion based on t-test was, there was a significant difference for both resins after they were soaked in water. Surface hardness number reduction in soaked thermoplastic nylon resin was $9.585 \%$ and in heat-cured acrylic resin was $12.938 \%$.

The surface hardness reduction in soaked thermoplastic nylon resin was $9.585 \%$. It was caused by higher porosity in thermoplastic nylon resin, and the existence of glass reinforced nylon in Valplast composition for $0.00001 \%$ (mineral dye). Glass reinforced nylon was added in order to repair water absorption in the material, but in fact, glass reinforced nylon was hygroscopic. ${ }^{17}$ Humidity as the result of water absorption can reduce resin's mechanical nature, that was, surface hardness. ${ }^{1,3,16,18}$

The surface hardness reduction in soaked heat-cured acrylic resin is 12.938 . It is caused by monomer remains in the material. Heat-cured acrylic resin contains monomer remains for 0.2 $0.5 \%{ }^{2}$ During polymerization process, not all monomers are converted into resin polymerization. The monomer remains can act as plasticizer which can affect the mechanical nature of denture base since it can reduce the tie force between chains so that it will be easier to have form change when 
mass is given during surface hardness test. ${ }^{7,20}$ Besides affecting surface hardness, monomer remains may cause porosity which facilitates water diffusion into polymer.

\section{CONCLUSION}

The surface hardness of thermoplastic nylon resin is lower than heat-cured acrylic resin, before or after soaking. This may be caused by different material composition of each resin. Besides, the different surface hardness number may be caused by polymerization method and polymer chain ties that are formed after polymerization.

\section{REFERENCES}

1. Anusavice KJ. Phillip's science of dental materials. $11^{\text {th }}$ ed. Philadelphia: W.B. Saunders Co.; 2003. p. 721-44.

2. Combe EC. Notes on dental materials. $6^{\text {th }}$ ed. Edinburgh: Churchill Livingstone; 1992. p. 157-63.

3. Craig RG, Powers JM. Restorative dental materials. $11^{\text {th }}$ ed. St. Louis: The C.V Mosby Co.; 2002. p. 636-50.

4. Hussain, Sharmila. Textbook of dental materials. $1^{\text {st }}$ ed. New Delhi: Jaypee Brothers Medical Publishers (P) Ltd.; 2004. p. 105-21.

5. Golbidi F, Asghari G. The level of residual monomer in acrylic denture base materials. Res J Biologic Sci 2009;4(2):244-9.

6. Jagger RG. Effect of the curing cycle on some properties of a poly methylmethacrylate denture base material. J Oral Rehabil 1978;5(2):151-7.

7. Azevedo A, Machado AL, Vergani CE, Giampaolo ET, Pavarina AC. Hardness of denture base and hard chair-side reline acrylic resins. J Appl Oral Sci 2005;13(3):291-5.

8. Pavarina AC, Machado AL, Giampaolo ET, Vergani CE. Effect of chemical desinfectants on the transverse strength of denture base acrylic resin. J Oral Rehabil 2003;30:1085-9.
9. Pfeiffer P, Rosenbauer EU. Residual methylmetacrylate monomer, water sorption and water solubility of hypoallergenic denture base materials. J Prosthet Dent 2004;92(1):72-8.

10. Fletcher AM, S.Purnajeva, Amin WM, Ritchie $\mathrm{GM}$, Moradians $\mathrm{S}$. The level of residual monomer in self-curing denture base materials. J Dent Res 1983;62:118-20.

11. ADA. Guide to dental materials and devices. $7^{\text {th }}$ ed. Chicago (Illinois): Am Dent Assoc; 1974. p. 97-9,203-6.

12. ISO 1567. Denture base polymers. Switzerland: Internasional Organization for Standardization; 1988.

13. Crawford RJ. Plastics engineering progress in polymer science. Vol 7. England: Pergamon Press; 1981. p. 7-9,128-33.

14. ASTM E 92-82. Standart test method for Vickers hardness. United States: ASTM Internasional; 1997.

15. Ilmillda. Perbandingan nilai porositas resin nilon termoplastik dan resin akrilik heat-cured berdasarkan kecepatan gelombang ultrasonik dengan ketebalan yang berbeda. Minor thesis. Bandung: Universitas Padjadjaran; 2008.

16. Callister WD. Materials science and engineering. $2^{\text {th }}$ ed. United States: John Wiley \& Sons, Inc; 1991. p. 209-27.

17. Valplast International Corp. Valplast flexible partials. 2007. [cited 2009 Mar]. Available online from: http/www.valplast.com.

18. O'Brien WJ. Dental materials and their selection. $3^{\text {th }}$ ed. Canada: The Quinstessence Publishing; 2002. p. 74-85.

19. Campanha NH, Pavarina AC, Vergani CE, Machado AL. Effect of microwave sterilization and water storage on the Vickers hardness of acrylic resin denture teeth. J Prosthet Dent 2005;93:483-6.

20. Neppelenbroek KH, Pavarina AC, Vergani CE, Giampaolo ET. Hardness of heat-polymerized acrylic resins after desinfection and long-term water immersion. J Prosthet Dent 2005;93:1716. 